\title{
PENGEMBANGAN LEMBAR KEGIATAN PESERTA DIDIK HIDROLISIS GARAM BERBASIS HIERARKI KONSEP
}

\author{
Yunika Devia, R. Usman Rery, Asmadi M. Noer *, Oktafianus
}

Program Studi Pendidikan Kimia, Fakultas Keguruan dan Ilmu Pendidikan Universitas Riau, Kampus Binawidya KM 12,5, Pekanbaru 28293, Riau, Indonesia.

\begin{tabular}{l}
\hline \multicolumn{1}{c}{ Informasi Artikel } \\
\hline Sejarah Artikel: \\
Diterima: 20-06-2019 \\
Disetujui: 27-01-2020 \\
Dipublikasikan: 28-01-2020 \\
\hline Keywords: \\
Student Activities \\
Worksheet, \\
Hierarchy Concept, \\
Salt Hydrolysis \\
\end{tabular}

\begin{abstract}
A b s t r a k
Penelitian ini merupakan penelitian desain untuk memperoleh prototype produk bahan ajar Lembar Kegiatan Peserta didik (LKPD). LKPD yang hendak dirancang dan dikembangkan adalah LKPD Berbasis Hierarki Konsep untuk Pokok Bahasan Hidrolisis Garam. Model pengembangan 4-D: Define, Design, Develop dan Disseminate. Tahap Define/ merumuskan kebutuhan mahasiswa serta mensinkronisasi indiktor/kempetensi yang ingin dicapai peserta didik dalam memahami materi HG. Tahap Desain merupakan rancangan LKPD yang sudah mempertimbangkan tercakupnya semua indikator tujuan pembelajaran berbasis BHK yang termuat pada LKPD. Hasil akhir tahap Desain adalah draf final LKPD (prototype) yang harus divalidasi yang dilaksanakan pada tahap Develop (pengembangan). Validasi LKPD oleh tiga orang pakar yang menilai aspek kelayakan content (isi), kebahasaan, sajian dan kegrafisan yang berturutturut mendapat skor $89,28 \%, 91,67 \%, 93,75 \%$ dan $87,50 \%$ dengan kategori valid. Setelah LKPD dinyatakan valid, LKPD diuji cobakan kepada siswa SMA untuk melihat respon dan masukan dari guru bidang studi kimia. Respon 20 orang siswa menilai positif/bermanfaat dengan skor $91,07 \%$ dengan kategori sangat positif dan dinilai kepraktisannya oleh dua orang guru dan mendapatkan hasil respons dengan persentase sebesar $93,75 \%$ dengan kategori sangat praktis.
\end{abstract}

\section{A b s t r a c t}

This research is a research design to obtain a product prototype teaching material Student Activity Sheet (LKPD). LKPD to be designed and developed is the Concept Hierarchy Based LKPD for Salt Hydrolysis Subjects. The research method used was the research development of Sivasailam Thiagarajan et al. 4-D development model: Define, Design, Develop and Disseminate. Define stage/formulate student needs and synchronize the indicators/competencies that students want to achieve in understanding the HG material. The Design Stage is a designation of LKPD which has considered the inclusion of all BHK-based pursuit objective indicators contained in LKPD. The final result of the Design stage is the final draft of the LKPD (prototype) which must be validated which is carried out at the Develop stage. LKPD validation by three experts who assessed the feasibility aspects of content, linguistics, presentation and graphics, respectively scored $89.28 \%, 91.67 \%, 93.75 \%$ and $87.50 \%$ with valid categories. After LKPD was declared valid, LKPD was tested on high school students to see the responses and input from the teacher in the field of chemistry studies. Response of 20 students rated positive/useful with a score of $91.07 \%$ in the very positive category and assessed its practicality by two teachers and got the response results with a percentage of $93.75 \%$ with a very practical category. 
*Alamat korespondensi:

e-mail: asmadim.noer@lecturer.unri.ac.id (AMN).

\section{PENDAHULUAN}

Seiring dengan perkembangan dan kemajuan dunia pendidikan, guru dituntut untuk selalu meningkatkan kualitas proses pembelajaran, menyelenggarakan kegiatan pembelajaran yang aktif, efektif dan menyenangkan sehingga dapat memberikan pengalaman belajar yang berkesan bagi peserta didik (Isworini et al., 2015). Salah satu faktor yang secara langsung bersinggungan dengan kegiatan pembelajaran peserta didik di kelas dan mempengaruhi kemampuan peserta didik adalah keberadaan sumber belajar (Kurnia et al., 2014). Berdasarkan PP nomor 19 tahun 2005 Pasal 20, guru diharapkan mengembangkan materi pembelajaran, yang kemudian dipertegas melalui Peraturan Menteri Pendidikan Nasional nomor 41 tahun 2007 tentang Standar Proses, yang antara lain mengatur tentang perencanaan proses pembelajaran yang mensyaratkan bagi pendidik untuk mengembangkan rencana pelaksanaan pembelajaran (RPP). Salah satu elemen dalam RPP adalah sumber belajar. Dengan demikian, guru diharapkan untuk mengembangkan bahan ajar sebagai salah satu sumber belajar bagi peserta didik (Direktorat Pembinaan SMA, 2008).

Bahan ajar adalah segala bentuk bahan yang digunakan untuk membantu guru atau pendidik dalam melaksanakan proses pembelajaran di kelas. Bahan ajar disusun secara sistematis, baik tertulis maupun tidak tertulis, sehingga tercipta lingkungan atau suasana yang memungkinkan peserta didik untuk belajar (Andi Prastowo, 2011). Salah satu bahan ajar yang dapat digunakan oleh guru dalam proses pembelajaran adalah Lembar Kegiatan Peserta Didik (LKPD), yaitu bahan ajar cetak berupa lembaran-lembaran yang berisi materi, ringkasan dan petunjuk-petunjuk pelaksanaan tugas yang harus dikerjakan oleh peserta didik yang mengacu pada kompetensi dasar yang dicapai (Direktorat Pembinaan SMA, 2008). Menurut Arafah et al., (2012), dengan adanya LKPD maka akan terbentuk interaksi yang efektif antara peserta didik dengan guru, sehingga dapat meningkatkan aktivitas belajar dan prestasi belajar peserta didik. Berdasarkan hasil wawancara dengan guru kimia di SMAN 6 Pekanbaru dan SMAS Serirama YLPI Pekanbaru terhadap ketersediaan dan pemanfaatan LKPD dalam proses pembelajaran, diketahui bahwa kebanyakan LKPD yang digunakan guru dalam proses pembelajaran tidak dibuat sendiri oleh guru, melainkan membeli ke penerbit. LKPD yang berasal dari penerbit secara umum berisi ringkasan materi, soal-soal, remedial dan pengayaan, sehingga jika guru hanya mengandalkan LKPD yang seperti ini maka peserta didik tidak akan dapat memahami konsep dengan baik dan mengonstruksi pengetahuan yang dimilikinya. Oleh karena itu dibutuhkanlah suatu LKPD yang dapat digunakan oleh guru untuk meningkatkan dan mengkonstruksi pemahaman konsep peserta didik dari yang sederhana hingga komplek (Lya Deni Prilianti et al., 2018).

Salah satu LKPD yang dapat membantu meningkatkan dan mengonstruksi pemahaman konsep peserta didik adalah LKPD berbasis hierarki konsep. Hierarki konsep adalah susunan kemampuan pemahaman dari sesuatu yang sederhana hingga ke kompleks, yang dari hal tersebut dapat diketahui seperangkat prasyarat bagi setiap komponen yang akan dipelajari (Retno et al, 2015). Jika peserta didik belum memahami materi prasyarat maka hal ini menunjukkan bahwa peserta didik belum siap untuk mempelajari materi berikutnya. Hierarki konsep yang diterapkan pada LKPD dapat memberi penguatan pada peserta didik untuk menghadapi persoalan dengan langkah penyelesaian yang sistematis (Kurniawati, 2010). Materi kimia yang membutuhkan pemahaman konsep peserta didik dari yang sederhana hingga kompleks adalah materi hidrolisis garam. Materi hidrolisis garam mengajarkan peserta didik bahwa garam itu tidak hanya netral, tetapi ada yang bersifat asam dan basa. Sehingga untuk memahami materi hidrolisis garam ini dibutuhkan hierarki konsep yang baik yang menyebabkan 
peserta didik dapat meningkatkan dan mengonstruksi pemahamannya sendiri dan dapat mengurangi miskonsepsi terhadap materi hidrolisis garam.

Berdasarkan uraian tersebut, maka penulis tertarik untuk mengembangkan suatu LKPD berbasis hierarki konsep pada materi hidrolisis garam, sehingga diharapkan dengan LKPD yang dikembangkan dapat membantu peserta didik dalam memahami konsep hidrolisis garam.

\section{METODE PENELITIAN}

Penelitian ini merupakan jenis Penelitian dan Pengembangan (Research and Development) yang mengacu pada desain penelitian dan pengembangan dari S. Thiagarajan yang dikenal dengan model 4-D yaitu Define (Pendefinisian), Design (Perencanaan), Develop (Pengembangan) dan Disseminate (Penyebaran). Namun karena keterbatasan waktu dan biaya, maka penelitian ini hanya dilakukan sampai tahap pengembangan (Develop). Alur pengembangan LKPD hidrolisis garam berbasis hierarki konsep dapat dilihat pada gambar 1 .

Penelitian ini dilaksanakan di Fakultas Keguruan dan Ilmu Pendidikan Program Studi Pendidikan Kimia. Subjek penelitian ini adalah ahli materi serta peserta didik kelas XI MIA SMAN 6 Pekanbaru dan SMAS Serirama YLPI Pekanbaru. Teknik pengumpulan data yang digunakan pada penelitian ini adalah dengan melakukan validasi LKPD oleh ahli materi serta respons pengguna. Instrumen penelitian yang digunakan adalah lembar validasi ahli materi, lembar respons guru dan peserta didik sebagai pengguna LKPD yang telah dikembangkan.

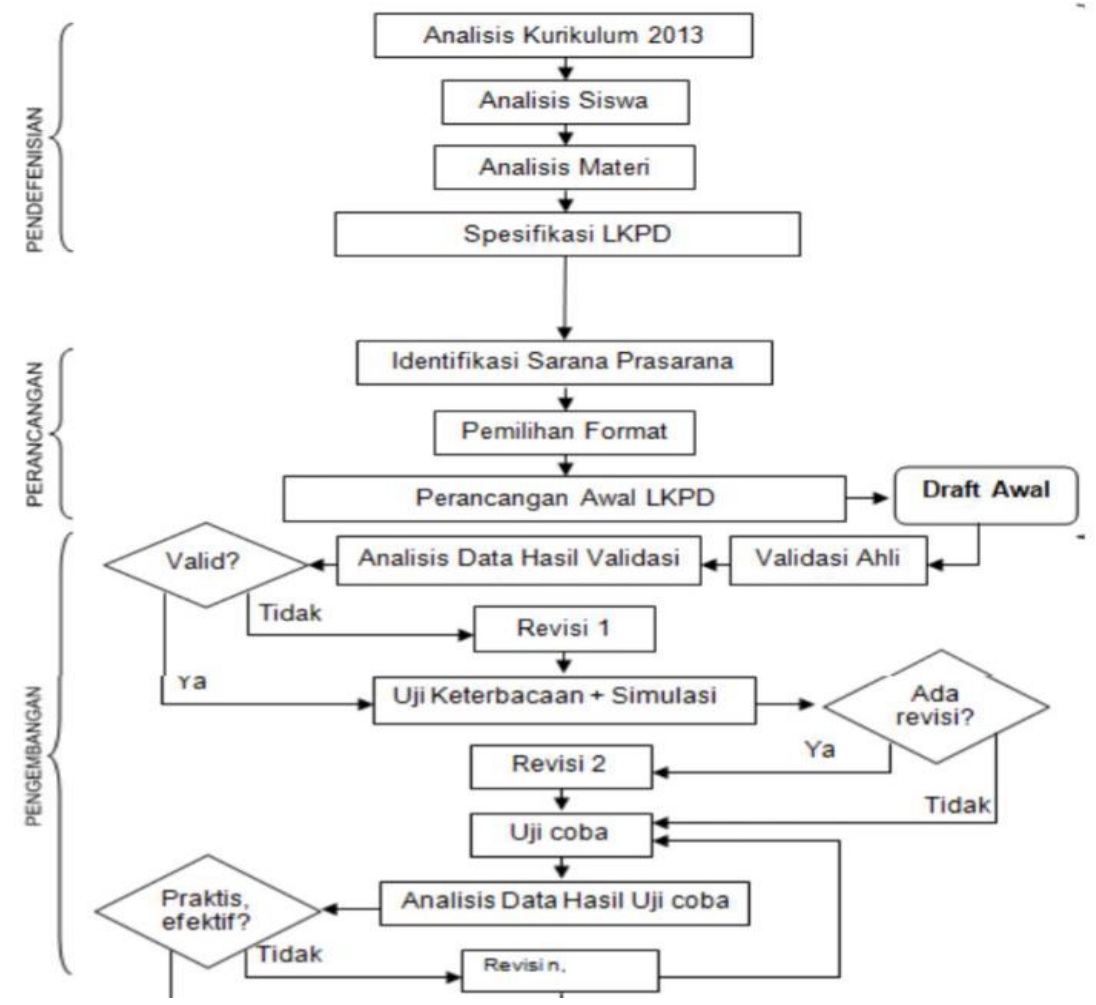

Gambar 1. Alur Pengembangan LKPD Hidrolisis Garam Berbasis Hierarki Konsep

Teknik analisis data yang digunakan adalah teknik analisis deskriptif kuantitatif, yaitu dengan cara menghitung rata-rata dari setiap aspek penilaian yang terdapat pada masingmasing aspek pada lembar validasi ahli materi dan lembar respons pengguna untuk 
mengetahui kelayakan, kepraktisan dan kemenarikan LKPD hasil pengembangan dengan menggunakan rumus (Suharsimi Arikunto, 2013) sebagai berikut:

$$
\mathrm{P}=\frac{\mathrm{S}}{\mathrm{N}} \times 100 \%
$$

Keterangan:

$\mathrm{P}=$ Persentase

$\mathrm{S}=$ Skor yang diperoleh

$\mathrm{N}=$ Skor maksimum

Pedoman dalam pengambilan keputusan dari analisis data menggunakan skala kualifikasi untuk menentukan kesimpulan. Kriteria kualifikasi hasil validasi dan respons pengguna disajikan dalam tabel 1 berikut:

Tabel 1. Kriteria Tingkat Kelayakan (Riduwan, 2009; Sa'dun Akbar, 2013)

\begin{tabular}{lll}
\hline Persentase (\%) & Kriteria Kelayakan & Kriteria Kepraktisan \\
\hline $81-100$ & Sangat Layak & Sangat Praktis \\
$61-80$ & Layak & Praktis \\
$41-60$ & Cukup Layak & Cukup Praktis \\
$21-40$ & Tidak Layak & Kurang Praktis \\
$0-20$ & Sangat Tidak Layak & Tidak Praktis \\
\hline
\end{tabular}

\section{HASIL PENELITIAN DAN PEMBAHASAN}

Berdasarkan hasil penelitian pengembangan LKPD hidrolisis garam menggunakan model pengembangan 4-D, diperoleh data mengenai proses pengembangan LKPD dan data hasil uji coba LKPD hidrolisis garam berbasis hierarki konsep sebagai berikut:

\section{Difine (Pendefinisian)}

Pada tahap ini dilakukan investigasi awal yang meliputi analisis kurikulum, peserta didik dan materi. Hasil analisis kurikulum yaitu diketahui bahwa kurikulum yang diterapkan di SMAN 6 Pekanbaru dan SMAS Serirama YLPI Pekanbaru saat ini adalah kurikulum 2013 revisi, dimana berdasarkan kurikulum 2013 revisi guru dituntun untuk mengembangkan suatu bahan ajar mandiri yang dapat digunakan oleh peserta didik sebagai sumber belajar mandiri. Namun kenyataan yang ada di SMAN 6 Pekanbaru dan SMAS Serirama YLPI Pekanbaru saat ini masih menggunakan LKPD yang dibeli dari penerbit yang membuat peserta didik kurang memahami materi pembelajaran khususnya hidrolisis garam secara baik dan pemahaman konsep peserta didik tidak tersusun secara sistematis atau tidak teratur dari yang sederhana hingga kompleks.

Selanjutnya analisis peserta didik dilakukan dengan cara wawancara terhadap peserta didik. Hasil analisis diketahui bahwa peserta didik yang menduduki Sekolah Menengah Atas pada umumnya adalah memasuki usia 16 - 17 tahun yang telah memasuki tahap operasional formal. Menurut teori perkembangan kognitif, pada tahap ini peserta didik mampu berpikir secara konseptual dan sistematis sehingga mampu mengkontruksi konsepnya sendiri dan hasil wawancara diketahui bahwa peserta didik kurang tertarik mengikuti proses pembelajaran karena bahan ajar LKPD yang disediakan guru kurang menarik dan hanya berisi uraian materi, rumus-rumus dan soal-soal sehingga membuat peserta didik merasa bosan dalam pembelajaran kimia khususnya materi hidrolisis garam.

Selanjutnya dilakukan analisis materi dengan cara menelaah silabus mata pelajaran kimia kelas XI dan telaah literatur. Hasil telaah diketahui bahwa materi hidrolisis garam terdiri dari konsep- 
konsep yang sederhana hingga konsep yang kompleks dan diketahui bahwa peserta didik mengalami kesulitan dalam memahami konsep-konsep hidrolisis garam.

Berdasarkan tahap difine (perencanaan) maka LKPD yang digunakan pada penelitian ini adalah LKPD hidrolisis garam berbasis hierarki konsep dimana informasi-informasi mengenai materi hidrolisis garam disusun secara teratur dari yang sederhana hingga kompleks sehingga peserta didik dapat mengkontruksi pemahamannya.

\section{Design (Perencanaan)}

Pada tahap ini dilakukan identifikasi sarana dan prasarana, pemilihan format serta perencangan awal LKPD. Berdasarkan hasil observasi dan wawancara guru kimia SMAN 6 Pekanbaru dan SMAS Serirama YLPI Pekanbaru diketahui bahwa sarana dan prasarana pembelajaran cukup memadai, meskipun masih ada beberapa sarana dan prasarana yang belum tersedia. Namun untuk menunjang pelaksanaan pengembangan LKPD ini telah memadai.

Setelah diketahui bahwa sarana dan prasarana pengembangan LKPD memadai maka dilanjutkan pemilihan format LKPD. Format penyusunan LKPD hidrolisis garam berbasis hierarki konsep ini berdasarkan pada format penyusunan LKPD yang dijelaskan pada Pemendikbud No. 65 tahun 2013, dimana pada suatu LKPD memuat Kompetensi Dasar, Tujuan, Petunjuk Penggunaan, Informasi Pengantar, Pertanyaaan Penyelidikan, Kesimpulan, Penilaian dan Daftar Rujukan. Selanjutnya format ini akan divalidasi pada tahap pengembangan selanjutnya.

Setelah dilakukan pemilihan format LKPD selanjutnya dilakukan perancangan awal LKPD yang dilakukan dengan mencari materi-materi terkait dengan materi hidrolisis garam kemudian materi tersebut disusun berdasarkan format dan sesuai dengan tuntutan kompetensi.

\section{Develop (Pengembangan)}

Tahap ini bertujuan untuk menghasilkan bentuk akhir LKPD hidrolisis garam. Bentuk akhir dari LKPD ini akan selesai setelah dilakukan revisi berdasarkan masukkan dari validator ahli materi dan respon pengguna. Instrumen penilaian kelayakan yang digunakan adalah lembar validasi ahli materi dan lembar respon pengguna (guru dan peserta didik). Rekap rata-rata penilaian kelayakan LKPD oleh ahli materi dapat dilihat pada gambar 2.

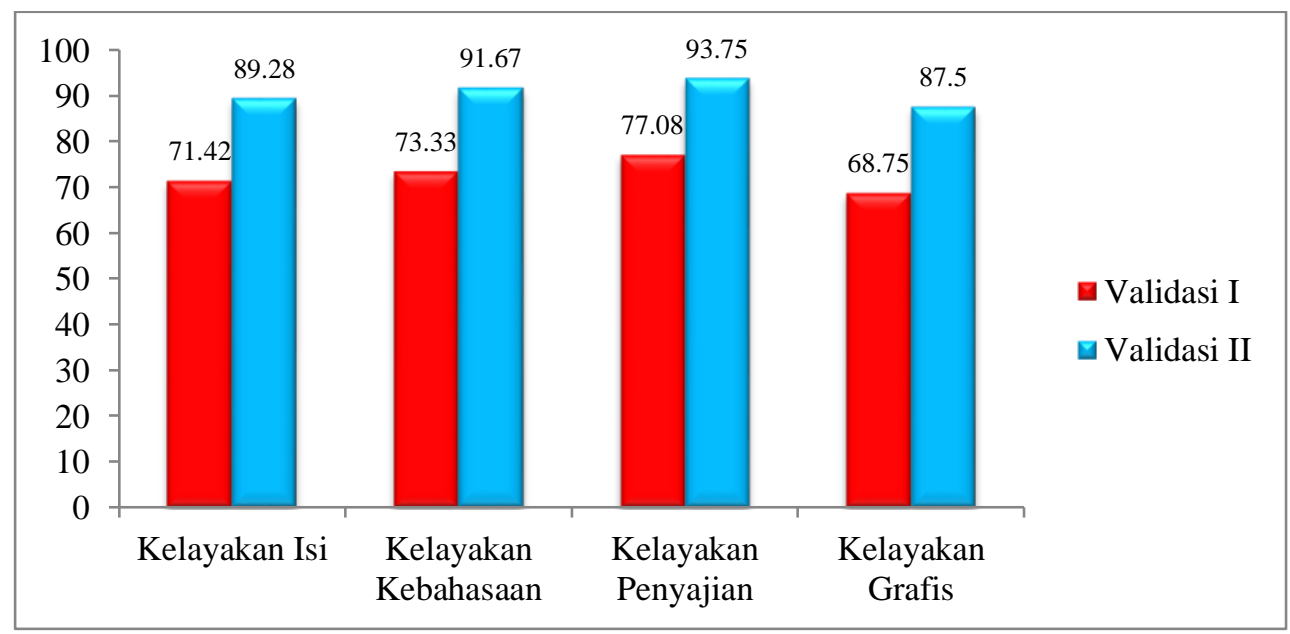

Gambar 2. Rekap Rata-rata Penilaian Kelayakan LKPD oleh Ahli Materi

Berdasarkan gambar 2. diketahui bahwa rata-rata skor aspek kelayakan isi, kelayakan kebahasaan, kelayakan penyajian dan kelayakan kegrafisan LKPD menurut ahli materi pada validasi I secara berturut-turut adalah 71,42\%, 73,33\%, 77,08\% dan 68,75\% dengan kategori kelayakan layak (Riduwan, 2009). Pada validasi II secara berturut-turut adalah 89,28\%, 91,67\%, 93,75\% dan 87,50\% dengan kategori kelayakan sangat layak (Riduwan, 2009), sehingga LKPD yang telah dikembangkan 
telah sesuai dengan kompetensi dasar yang harus dicapai sesuai silabus pembelajaran kimia kurikulum 2013 revisi. Hal ini sesuai dengan pendapat Prastowo (2012) bahwa LKPD yang baik harus memiliki kesesuaian antara materi dan kompetensi yang akan dicapai. LKPD yang telah dikembangkan secara sistematis dan sesuai dengan tahapan hierarki konsep ini dapat digunakan dalam membantu peserta didik untuk menemukan konsep dengan mengurutkan konsep dari yang sederhana hingga ke komplek, sehingga peserta didik dapat melangsungkan pembelajaran secara mandiri. Hal ini sejalan dengan pendapat Abdul Majid (2013) yang menyatakan bahwa konsep dasar dari pembelajaran mandiri adalah struktur yang ditandai dengan adanya suatu susunan atau hierarki tertentu. Gagne (dalam Thobroni, 2016) menyatakan bahwa belajar dimulai dari hal yang paling sederhana dan dilanjutkan dengan yang lebih kompleks. LKPD yang disusun secara sistematis akan mendorong peserta didik untuk belajar secara mandiri.

Setelah LKPD hidrolisis garam berbasis hierarki konsep dinyatakan layak oleh ahli materi maka LKPD diujikan kepada pengguna yaitu guru dan peserta didik untuk mengetahui kepraktisan dalam menggunakan LKPD yang telah dikembangkan. Uji pengguna ini dilakukan kepada guru kimia dan peserta didik SMAN 6 Pekanbaru dan SMAS Serirama YLPI Pekanbaru. Persentase hasil uji respons guru kimia kedua sekolah adalah 93,75\% dengan kategori sangat praktis. Sedangkan persentase hasil uji respons peserta didik dapat dilihat pada gambar 3 berikut:

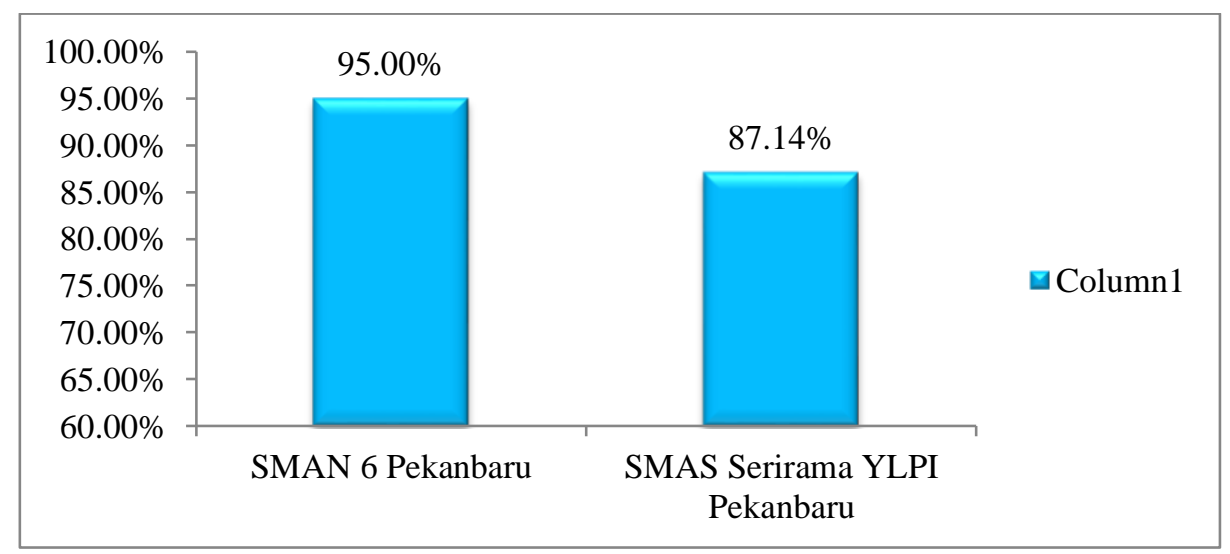

Gambar 3. Persentase Hasil Uji Respons Peserta Didik

Berdasarkan gambar 3. diketahui bahwa rata-rata respons peserta didik SMAN 6 Pekanbaru adalah 95\% dan SMAS Serirama YLPI Pekanbaru adalah 87,14\% dengan kategori sangat praktis. Sehingga dari hasil uji respons pengguna guru kimia dan peserta didik diketahui bahwa LKPD yang telah dikembangkan dapat terbaca dan dipahami dengan baik oleh pengguna baik guru maupun peserta didik. Selain itu, menurut peserta LKPD sangat menarik karna menampilkan gambar-gambar yang sangat mendukung pemahaman konsep peserta didik dan meningkatkan motivasi peserta didik dalam belajar kimia khususnya materi hidrolisis garam.

\section{KESIMPULAN}

Berdasarkan hasil penelitian, analisis data dan pembahasan dapat disimpulkan bahwa Lembar Kegiatan Peserta Didik (LKPD) hidrolisis garam berbasis hierarki konsep telah berhasil dikembangkan dengan desain penelitian dan pengembangan (R\&D) model 4-D. Validasi LKPD menurut ahli materi dinyatakan sangat valid dan dapat digunakan dalam proses pembelajaran kimia dan hasil uji respons pengguna diketahui LKPD sangat praktis dan sangat menarik untuk digunakan dalam proses pembelajaran kimia. 


\section{DAFTAR PUSTAKA}

Abdul Majid. 2013. Strategi Pembelajaran. Remaja Rosda Karya. Bandung

Andi Prastowo. 2014. Pengembangan Bahan Ajar Tematik (Tinjauan Teoretis dan Praktik). Kencana. Jakarta

Arafah, S. F., B. Priyono, dan S. Ridlo. 2012. Pengembangan LKS berbasis berpikir kritis pada materi animalia. Unnes Journal of Biology Education. 1(1): 75-81

Direktorat Pembinaan SMA. 2008. Panduan Pengembangan Bahan Ajar. Departemen Pendidikan Nasional. Jakarta

Isworini, Widha Sunarno dan Sulistyo Saputro. 2015. Pengembangan Modul Pembelajaran Hidrolisis Garam Berbasis Model Inkuiri Terbimbing (Guidedinquiry) untuk Siswa Madrasah Aliyah Kelas XI. Jurnal Inkuiri 4 (3): 9-20

Kurnia F, Zulherman dan A. Fathurohman. 2014. Analisis bahan ajar fisika SMA kelas XI di kecamatan Indralaya Utara berdasarkan kategori literasi sains. Jurnal Inovasi dan Pembelajaran Fisika. 1 (1): 43-47

Kurniawati, W. D. 2010. Penerapan Model Pembelajaran Leraning Cycle 5 Fase untuk Meningkatkan Aktivitas dan Penguasaan Konsep Pokok Bahasan Asam Basa. SKRIPSI. Bandar Lampung: FKIP Universitas Lampung.

Lya Deni Prilianti, Dedeh Kurniasih dan Fitriani. 2018. Analisis Kevalidan LKS Berbasis Hierarki Konsep pada Materi Kelarutan dan Hasil Kali Kelarutan. Jurnal Pendidikan Informatika dan Sains 7 (1)

Retno, A. T. P., Sulistyo, S. \& Budi, U. 2015. Pengembangan Media Pembelajaran Buletin dalam Bentuk Buku Saku Berbasis Hierarki Konsep untuk Pembelajaran Kimia Kelas XI Materi Hidrolisis Garam. Jurnal Pendidikan Kimia. 4(2): 74-81

Riduwan. 2009. Skala Pengukuran Variabel-variabel Penelitian. Alfabeta. Jakarta

Sa'dun Akbar. 2013. Instrumen Perangkat Pembelajaran. Rosdakarya. Bandung

Suharsimi Arikunto. 2013. Prosedur Penelitian (Suatu Pendekatan Praktik) edisi Revisi VI. Bumi Aksara. Jakarta

Thobroni, M. 2016. Belajar dan Pembelajaran. Ar-Ruzz Media. Jakarta 